\title{
Awareness of Genetic Polymorphism in Drug Metabolizing Enzymes and Transporters May Promote Personalized Type 2 Diabetes Management [Response to Letter]
}

\author{
David M Williams $\mathbb{D}^{\prime}$, Jeffrey W Stephens $\mathbb{B D}^{1,2}$ \\ 'Department of Diabetes and Endocrinology, Morriston Hospital, Swansea Bay University Health Board, Swansea, SA6 8NL, UK; ${ }^{2}$ Diabetes Research \\ Group, Swansea University Medical School, Swansea University, Swansea, SA2 8PP, UK \\ Correspondence: David M Williams, Diabetes Centre, Morriston Hospital, Swansea, SA6 6NL, UK, Tel +44I792704078, Email david.williams@doctors.org.uk
}

\section{Dear editor}

We have read the letter to the editor by Zhu and Zhou and would like to thank the authors for their interesting comments. We agree with the authors' observations, which highlight some of the complexities associated with the personalized management of patients with type 2 diabetes (T2D) raised in our recently published review. ${ }^{1}$

We concur that further work needs to be undertaken to explore the importance of pharmacogenomics in people with T2D. The authors summarize the implications of pharmacogenomics on the metabolism and therefore the efficacy and sideeffect profiles of older classes of diabetes medications including metformin, sulphonylureas, and thiazolidinediones. However, the implications of pharmacogenomics in the response to newer therapies for T2D remains relatively unknown. ${ }^{2,3}$ Interestingly, DNA and plasma are increasingly obtained prospectively in Phase III clinical trials evaluating newer diabetes pharmacotherapies to determine genetic and biochemical variables which associate with therapy efficacy. ${ }^{4,5}$ Naturally, this has the potential to provide a major opportunity to profile genetic variants which affect the pharmacokinetics of current drug therapies utilised for T2D. This may develop our understanding of the role for pharmacogenomics for both glycemic and non-glycemic benefits (eg, cardiovascular, renal, and hepatic outcomes) and adverse effects associated with various drug treatments for T2D.

Regrettably, the routine use of genetic profiling in people with T2D is not yet readily available to permit these findings a role in the modern treatment of people with T2D. Clearly for there to be a role for pharmacogenomics in a personalized treatment approach, such genomic testing would at least need to be readily available for most patients. ${ }^{3}$ Clearly, in order to adopt such a personalized approach, a greater evidence base must be developed, and well-designed prospective trials examining gene-drug interactions are needed. We trust that with our developing understanding of the use of pharmacogenomics in the treatment of people with T2D, that easily accessible technology to support clinicians will be developed in future. Indeed, such an approach has the potential to not only improve treatment choices for people with T2D but also to minimise the burden associated with failed drug treatments on healthcare services and the economic costs associated with the prescription of inappropriate medicines.

Again, we would like to thank Zhu and Zhou for their comments in response to our review article and for highlighting the importance of genetic polymorphisms in the treatment response in people with T2D to currently available pharmacotherapies.

\section{Disclosure}

The authors report no conflicts of interest in this communication. 


\section{References}

1. Williams DM, Jones H, Stephens JW. Personalized type 2 diabetes management: an update on recent advances and recommendations. Diabetes Metab Syndr Obes. 2022;15:281-295. doi:10.2147/DMSO.S331654

2. Pearson ER. Diabetes: is there a future for pharmacogenomics guided treatment? Clin Pharmacol Ther. 2019;106:329-337. doi:10.1002/cpt.1484

3. Zeng Z, Huang SY, Sun T. Pharmacogenomic studies of current antidiabetic agents and potential new drug targets for precision medicine of diabetes. Diabetes Ther. 2020;11:2521-2538. doi:10.1007/s13300-020-00922-x

4. Zimdahl H, Ittrich C, Graefe-Mody U, et al. Influence of TCF7L2 gene variants on the therapeutic response to the dipeptidylpeptidase-4 inhibitor linagliptin. Diabetologia. 2014;57:1869-1875. doi:10.1007/s00125-014-3276-y

5. Daniels MA, Kan C, Willmes DM, et al. Pharmacogenomics in type 2 diabetes: oral antidiabetic drugs. Pharmacogenomics J. 2016;16:399-410. doi:10.1038/tpj.2016.54

Dove Medical Press encourages responsible, free and frank academic debate. The content of the Diabetes, Metabolic Syndrome and Obesity: Targets and Therapy 'letters to the editor' section does not necessarily represent the views of Dove Medical Press, its officers, agents, employees, related entities or the Diabetes, Metabolic Syndrome and Obesity: Targets and Therapy editors. While all reasonable steps have been taken to confirm the content of each letter, Dove Medical Press accepts no liability in respect of the content of any letter, nor is it responsible for the content and accuracy of any letter to the editor.

Diabetes, Metabolic Syndrome and Obesity: Targets and Therapy

\section{Publish your work in this journal}

Diabetes, Metabolic Syndrome and Obesity: Targets and Therapy is an international, peer-reviewed open-access journal committed to the rapid publication of the latest laboratory and clinical findings in the fields of diabetes, metabolic syndrome and obesity research. Original research, review, case reports, hypothesis formation, expert opinion and commentaries are all considered for publication. The manuscript management system is completely online and includes a very quick and fair peer-review system, which is all easy to use. Visit http://www.dovepress. com/testimonials.php to read real quotes from published authors.

Submit your manuscript here: https://www.dovepress.com/diabetes-metabolic-syndrome-and-obesity-targets-and-therapy-journal 